\title{
Kestävän kulutuksen ja tuotannon ohjelman uudistaminen elintarvikesektorilla - ruokaketjun nykytila, haasteet ja keinot kestävyyden edistämiseksi
}

\author{
Inkeri Riipi ${ }^{1)}$ ja Sirpa Kurppa ${ }^{1)}$ \\ ${ }^{1)}$ Maa- ja elintarviketalouden tutkimuskeskus (MTT), Biotekniikka- ja elintarviketutkimus, \\ Latokartanonkaari 9,00790 Helsinki,inkeri.riipi@mtt.fi, sirpa.kurppa@mtt.fi
}

\section{Tiivistelmä}

Runsas kolmannes kuluttajan kaikista ympäristövaikutuksista aiheutuu ruoasta. Erityisesti vesistöjen tilaan ruoan kulutuksella on suuri vaikutus, sillä ruokailu voi vastata puolta kulutuksen kaikista ravinnepäästöistä. Ilmastovaikutuksista ruoan osuus on hieman alhaisempi, vajaa 30 prosenttia. Tyypillinen länsimainen ruokavalio sisältää paljon lihaa, rasvaa ja sokeria, mikä on haitaksi paitsi yksilön terveydelle, myös ympäristölle. Ympäristövaikutuksia syntyy myös ruoan hävikistä. Jokainen suomalainen heittää roskiin syömäkelpoista ruokaa noin 25-30 kiloa vuosittain.

Nykyisten ohjauskeinojen suunnittelussa ei ole kiinnitetty huomiota siihen, mitkä olisivat suomalaisiin luonnonvarojen käyttöön perustuvat luontaisimmat ja rakenteellisesti kestävimmät tuotantoketjut ja niihin liittyvä kestävä maankäyttö. Myöskään kestävyystavoitteisiin ei ole vielä liitetty verotuskäytäntöä ja ohjauskeinojen kohdistuvuuteen tarvittaisiin lisää tehokkaampia keinoja. Lisäksi kotitalouksien tiedollinen ohjaus on vasta hyvin alkuvaiheessaan. Ympäristöä säästyy, kun luonnonvaroja käytetään säästeliäästi ja samalla säästetään myös kustannuksissa. Kuitenkaan kustannuslaskennassa ei ole huomioitu ympäristötoimien laiminlyömiseen liittyviä riskejä. Tärkeintä olisi kiinnittää huomio alkutuotannon ohjauskeinoihin, sillä valtaosa ruokajärjestelmämme ympäristövaikutuksista syntyy raaka-aineiden tuotannossa, siis maataloudessa.

Kestävyyden käytännöistä ja malleista on olemassa hyviä esimerkkejä Suomessa, kuten ConsenvLautsmalli tai Portaat Luomuun -ohjelma. Kestävyyttä ruokasektorilla voidaan edistää mm. kiinnittämällä huomiota kestäviin ruokajärjestelmiin ja markkinoihin, kestävään ruokavalioon, muutoksiin ruoan kulutuksessa sekä ruokapolitiikkaan. Hyvänä tarkastelumallina toimii myös vuosituhannen ekosysteemiarvio, mikä edellyttää, että kaikki ruokatalouden toimijat alkaisivat yhtenäisesti kehittää luonnonvaroja ja ympäristöä säästävää elintarvikejärjestelmää, siis suomalaisen ruoan kestävää laatua.

Tässä posterissa esitellään, alkuvuodesta 2012 julkaistavan kestävän kulutuksen ja tuotannon (KULTU) -ohjelman sisältöä, ts. sen taustaksi koostettuja keskeisiä elintarvikkeiden ympäristövaikutuksiin liittyviä tutkimuksia sekä keinoja kulutuksen ja tuotannon ympäristökuormitusten vähentämiseksi. Ohjelma julkaistiin ensimmäisen kerran vuonna 2005 ja syksystä 2010 alkaen sitä on päivitetty. Ympäristö- ja työ- ja elinkeinoministeriön yhteishankkeena käynnistetyn työn tavoitteena on ollut pohtia keinoja, miten yksityisen ja julkisen kulutuksen energiaja materiaalitehokkuutta voidaan parantaa tinkimättä elämänlaadusta. Valmistelutyössä on kehitetty myös ohjauskeinoja, joilla voidaan edistää arjen kestävyyttä sekä tukea kestävän infrastruktuurin rakentamista. Päämääränä on myös käynnistää kokeiluja, joilla voidaan testata uusia toimintamalleja sekä löytää uusia ratkaisuja.

Asiasanat: Kestävä tuotanto, kestävä kulutus, elintarvikeketju, ruoan tuotanto ja kulutus 


\section{Johdanto}

Luonnonvarojen kulutus on lisääntynyt merkittävästi viimeisten vuosikymmenien aikana. Vuodesta 1960 kulutuksemme on kuusinkertaistunut ja henkeä kohden laskettuna kulutus on kolminkertaistunut. Merkittävimmät syyt siihen ovat olleet väestön kasvu kehitysmaissa sekä varallisuuden ja kulutuksen kasvu kehittyneissä maissa. Ihmiskunta käyttää luonnonvaroja ja ekosysteemejä noin 1,3 maapallon verran. (Maailman tila 2010). Kulutamme siis enemmän kuin mihin meillä olisi varaa.

Maataloudessa päämääränä viime vuosikymmeninä on ollut raaka-aineiden tuotannon lisääminen ennen kaikkea satotasoja lisäämällä, ilman ympäristökustannuksia. Pyrkimykset edistää ruoan tuotantoa ja viljelytapojen nopea kehittyminen ovat kuitenkin vaikuttaneet negatiivisesti ekosysteemien ominaisuuksiin, esimerkiksi maaperän köyhtymisen ja biodiversiteetin vähenemisen kautta. (Nelleman ym. 2009).

Ruoan tuotantoon ja kulutukseen liittyy merkittäviä yhteiskunnallisia, ympäristöllisiä ja kulttuurisia vaikutuksia. Ruokavalintojen kautta voidaan vaikuttaa paitsi omaan terveyteen, myös ilmastonmuutokseen ja vesistöjen rehevöitymiseen, tuotantoeläinten kohteluun, maatalouselinkeinoon, kansainvälisen kaupan rakenteisiin jne. Koko hyvinvointimme riippuu ekosysteemin tarjoamista palveluista, tuotannolliset palvelut yhtenä osana niissä. Huomio on siis kiinnitettävä paitsi siihen, miten kuluttajat saadaan muuttamaan toimintatapojaan, myös siihen millä tekniikoilla ja tuotantojärjestelmillä pystymme tuottamaan ruokaa kestävästi ja millaisia toimenpiteitä tarvitaan politiikkatasolla kestävän ruoantuotannon edistämiseksi.

Tässä posterissa esitellään taustatyöaineistoa kestävän kulutuksen ja tuotannon ohjelmasta ja kuvataan ohjelman työn tuloksia kestävän elintarvikeketjun kannalta. Aluksi tarkastellaan ruokaketjun ympäristövaikutuksia ilmastonmuutos- ja rehevöitymisvaikutusten näkökulmasta sekä tuodaan esille ravitsemus- ja ympäristökytkennät. Tämän jälkeen esitellään käytössä olevia ohjauskeinoja ja niiden vaikuttavuutta. Pakollisten ohjauskeinojen, kuten lainsäädännön, verojen ja maksujen lisäksi tuodaan esille muutamia vapaaehtoisia toimenpiteitä. Kolmanneksi esitellään esimerkkejä kestävyyden käytännöistä ja malleista Suomessa. Lopuksi tuodaan esille kestävyyden edistämisen mahdollisuuksia ruokasektorilla.

\section{Ruokaketjun ympäristövaikutuksia}

Ruoankulutuksen merkitys suomalaisen kuluttajan ympäristövaikutuksissa on keskeinen. Runsas kolmannes kuluttajan kaikista ympäristövaikutuksista aiheutuu ruoasta. Erityisesti vesistöjen tilaan ruoan kulutuksella on suuri vaikutus, sillä ruokailu voi vastata puolta kulutuksen kaikista ravinnepäästöistä. Ilmastovaikutuksista ruoan osuus on hieman alhaisempi, vajaa 30 prosenttia. (Seppälä ym. 2009).

Rehevöittävien päästöjen vähentäminen ja vesistöjen tilan parantaminen ovat Suomen elintarviketuotannon ympäristövastuun kannalta keskeisessä asemassa. Kotimaisen elintarviketuotantoketjun osuus vesistöjen rehevöitymisestä on $57 \%$ ja ilmaston-muutoksessa $14 \%$. Elintarviketuotantoketjun maataloustoimintaan kuuluvat vaiheet hallitsevat ketjun ympäristökuormitusten muodostumista. Maatalouden osuus elintarvikeketjun ympäristövaikutusten kokonaisuudessa on reilusti yli puolet ja jalostavan teollisuuden osuus 0-5\%. Muiden ketjun vaiheiden osuus jää alle 30 prosenttiin. (Virtanen ym. 2009).

Elintarviketuoteryhmistä suurimmat ympäristövaikutukset aiheutuvat liha- ja maitotuotteiden käytöstä. Yhdessä nämä kaksi tuoteryhmää aiheuttavat 45-59 \% koko ketjun ympäristövaikutuksista ja 49-67 \% kotimaisista ympäristövaikutuksista. (Virtanen ym. 2009).

Suomalaisten asiantuntijoiden arvioissa globaalia muutosta aiheuttavat tekijät eli ilmastonmuutos, väestönkasvu ja globalisaatio ovat kaikki suurelta osin suomalaista ruoantuotantoa uhkaavia tekijöitä, mutta joissakin olosuhteissa myös tiettyjä mahdollisuuksia luovia muutosvoimia. (Kirveennummi ym. 2008). 


\section{Ravitsemuskytkennät}

Tyypillinen länsimainen ruokavalio sisältää paljon lihaa, rasvaa ja sokeria. Tämä on haitaksi paitsi yksilön terveydelle, myös yhteiskunnalle ja ympäristölle (SCAR 2011). Maailman terveysjärjestö WHO:n arvion mukaan ihminen tarvitsee noin 30-45 g proteiinia päivässä. EU:ssa keskimääräinen kulutus on $100 \mathrm{~g}$ per päivä, josta $66 \mathrm{~g}$ on eläinperäistä proteiinia (66 g proteiinia vaatii noin $200 \mathrm{~g}$ lihaa) (Watte, 2011). Globaaleista kasvihuonekaasupäästöistä $18 \%$ aiheutuu lihan tuotannosta. Nurmirehuun perustuva karjan tuotanto varsinkin heikkotuottoisilla alueilla vaatii laajoja laidunalueita, ja niin muodoin lisää kokonaismaakäytön tarvetta ja edistää metsien hävittämistä. Intensiivinen kotieläintuotanto ja erityisesti suuret tuotantoyksiköt johtavat helposti paikalliseen ympäristön pilaantumiseen. (Stehfest ym. 2009).

Ravitsemuksellisesti tasapainoisia lounasannoksia vertailleen ConsEnv -tutkimuksen (Saarinen ym. 2011) mukaan sekaruokalounaat kuormittavat ilmastoa 2-3-kertaisesti ja rehevöittävät vesistöjä 4-5kertaisesti verrattuna kasvisaterioihin. Useimmissa aterioissa pääruoka on kuormittavin aterian osa.

Kulutuksessa syntyvä ruokajäte lisää myös omalta osaltaan ruoan ympäristökuormituksia. Jokainen suomalainen tuottaa kotitaloudessaan noin 20-30 kg ruokahävikkiä/vuosi (yhteensä noin 120-160 miljoona kg). Lisäksi hävikkiä syntyy merkittäviä määriä myös kaupoissa ja ravintolasektorilla. (Silvennoinen \& Katajajuuri 2011).

\section{Käytössä olevia ohjauskeinoja}

Tällä hetkellä elintarvikeketjun alkutuotannossa haitallisten vesistövaikutusten vähentämisen tehokkaimpia ohjauskeinoja ovat typpilannoitusta säätelevä nitraattiasetus (931/2000) sekä EU:n osittain rahoittama maatalouden ympäristötukijärjestelmä, joiden tavoitteena on suojella vesistöjä maataloudesta peräisin olevilta ravinteilta ja vähentää yleisemminkin maatilojen ympäristökuormitusta sekä huolehtia luonnon monimuotoisuudesta ja maisemanhoidosta (YM 2008). Lisäksi ympäristönsuojelulaissa ja -asetuksessa on kotieläintalouden ympäristölupiin liittyviä säännöksiä, joilla on tärkeä merkitys maatalouden ympäristönsuojelussa. Muita elintarvikeketjun alku- ja tuotantopään kestävyyttä edistäviä lakeja ovat esimerkiksi Jätelaki, YVA -asetus tai vesilaki ja asetus. Tärkeitä säätelymekanismeja ovat myös erilaiset maksut ja verot, kuten jäte- ja energiavero, juomapakkausvero sekä kunnalliset jätemaksut.

Euroopan unionin yhteisillä maatalouteen liittyvillä määräyksillä ja ympäristömääräyksillä on varsin kattava vaikutus myös kansallisella tasolla. Tällaisia ovat $\mathrm{mm}$. maaperän ja vesiensuojelun puitedirektiivit, kasvinsuojeludirektiivi, direktiivi yhteisön politiikan puitteista kasvinsuojeluaineiden kestävän käytön aikaansaamiseksi sekä biodiversiteetin suojeluun liittyvät direktiivit, käytäntöön vietävät toimintaohjelmat kuten ympäristöteknologia-toimintaohjelma (ETAP Environmental Technology Action Plan) sekä biodiversiteetti-toimintaohjelma (Biodiversity action plan). Suomen kannalta keskeinen on myös kemikaalilaki, johon liittyvä virasto on sijoitettu Suomeen. Kestävyyttä pyritään edistämään EU:ssa erittäin monipuolisten politiikkatoimien avulla ja kansallisesti erilaisten viranomaismääräysten kautta. Näistä elintarvikeketjulle läheisimpänä esimerkkinä Valtioneuvoston periaatepäätös "kestävien valintojen edistämisestä julkisissa hankinnoissa", jossa on asetettu tavoitteeksi luonnonmukaisen, kasvisruoan ja sesongin mukaisen ruoan edistäminen julkisissa ruokapalveluissa.

Lainsäädännöllisten vaatimusten ja viranomaismääräysten lisäksi on olemassa joukko vapaaehtoisia keinoja tuotannon ympäristökuormitusten vähentämiseksi. Näitä ovat esimerkiksi erilaiset merkit tuotteissa, kuten hiilijalanjälki- sekä vesijalanjälkimerkit tai kalatuotteiden ympäristömerkintä MSC, sekä yritysten ympäristöjärjestelmät, joiden avulla yritykset pyrkivät toiminnan systematisoinnin kautta kehittämään toimintansa ympäristöasioita ja vähentämään ympäristökuormitusta. Merkeistä kattavin on Joutsenmerkki eli Pohjoismaiden yhteinen ympäristömerkki, joka on laajentumassa koskemaan myös elintarvikkeita, tarkemmin ottaen leipätuotteita vuodesta 2012 alkaen. Muita kestävää kulutusta ja tuotantoa edistäviä ohjauskeinoja ovat mm. erilaiset kampanjat (kuten biojätteen vähentämiskampanjat kouluissa ja ruokaloissa) ja koulutukset (kuten erilaiset kestävän kehityksen koulutukset ruokapalvelu ja ravintola-alalla, esim. ympäristöpassikoulutus). Erilaisten yhteisöllisten 
kehittämisprojektien, kansalais- ja vapaaehtoisjärjestöjen ja sosiaalisen median asema kestävyyskysymysten esiin nostossa, kestävyysajattelun kehittämisessä, ohjauskeinojen ennakko- ja jälkiarvioinnissa ja ohjauskeinojen toteuttamisen edistämisessä on koko ajan vahvistumassa.

Nykyisten ohjauskeinojen puutteena on kuitenkin se, ettei suunnittelussa ole kiinnitetty huomiota siihen, mitkä olisivat suomalaisiin luonnonvarojen käyttöön perustuvat luontaisimmat ja rakenteellisesti kestävimmät tuotantoketjut ja niihin liittyvä kestävä maankäyttö. Myöskään kestävyystavoitteisiin ei ole vielä liitetty mitään verotuskäytäntöä ja ohjauskeinojen kohdistuvuuteen tarvittaisiin lisää tehokkaampia keinoja. Lisäksi kotitalouksien tiedollinen ohjaus on vasta hyvin alkuvaiheessaan. Ympäristöä säästyy, kun luonnonvaroja käytetään säästeliäästi ja samalla säästetään myös kustannuksissa. Kuitenkaan kustannuslaskennassa ei ole huomioitu ympäristötoimien laiminlyömiseen liittyviä riskejä. Tärkeintä olisi kiinnittää huomio alkutuotannon ohjauskeinoihin, sillä valtaosa ruokajärjestelmämme ympäristövaikutuksista syntyy raaka-aineiden tuotannossa, siis maataloudessa.

\section{Esimerkkejä kestävyyden käytännöistä ja malleista}

Suomessa on kehitetty viime vuosina useita kiinnostavia malleja ja käytäntöjä kestävyyden edistämiseksi. Näistä esimerkkeinä on mm. MTT:n johdolla kehitetyt Consenv -laustamalli ja elintarvikeketjun vastuullisuuden teemakokonaisuus, Ecocentrian kehittämä Portaat Luomuun ohjelma ja ympäristöpassi sekä erilaiset kasvihuonekaasulaskurit.

Consenv -lautasmallissa (Saarinen ym. 2011) havainnollistetaan ateriavalintoja perinteistä ravitsemussuositusten mukaista lautasmallia mukaillen. Vertailua ja valintaa ympäristövaikutuksiltaan erilaisten raaka-aineiden suhteen tehdään siinä aterian osien sisällä. Elintarvikeketjun vastuullisuuden teemakokonaisuus (Forsman-Hugg ym. 2009) sisältää 7 osa-aluetta: ympäristö, tuoteturvallisuus, ravitsemus, työhyvinvointi, eläinten hyvinvointi, paikallisuus ja taloudellinen vastuu. Parhaillaan on kehitteillä vastuullisuuden teemoihin liittyvät kriteerit ja niihin edelleen liittyvät mittarit. Tulokset julkistetaan vuoden 2012 alussa.

Portaat Luomuun on EkoCentrian kehittämä vapaaehtoinen ohjelma, jonka tarkoituksena on auttaa ammattikeittiöitä lisäämään luomutuotteiden käyttöä osana kestävän kehityksen mukaista toimintaa. Ohjelman rakentuu yrityksen peruslupauksille, jotka ovat luotettava ja kestävän kehityksen mukainen toiminta. Näiden lupausten lunastamiseksi ohjelma asettaa ohjelmaan liittyville ammattikeittiölle tietyt vaatimukset ja edellyttää yritysten noudattavan tiettyjä suosituksia. Savon aikuis- ja ammattiopiston Ekocentria -yksikön muiden yhteistyötahojen kanssa yhteistyössä kehittämä ympäristöpassi on matkailu- ravitsemis- ja talousalan ammattilaisille ja opiskelijoille suunnattu valmennusaineisto ja osaamistesti ruokapalveluiden ympäristöasioista. Se käsittelee keskeiset ruokapalveluiden ympäristövaikutukset, korostaen erityisesti ruoan alkutuotannon ja keittiön laitteiden energiankulutuksen kysymyksiä ja keittiön ja asiakaspalvelun kestäviä toimintatapoja.

Viime aikoina on julkaistu useita erilaisia kasvihuonekaasuvaikutuksiin liittyviä laskureita. Ilmastodieetti on työkalu omien kasvihuonekaasupäästöjen seuraamiseen ja vähentämiseen. Ruokaan liittyvästä nimestä poiketen työkalu ottaa huomioon ruoan lisäksi asumiseen, energiankäyttöön, jätteisiin, liikkumiseen ja kulutukseen liittyvät kasvihuonekaasupäästöt. Vastaava toinen vaihtoehto on mm. HS hiilijalanjälkilaskuri.

\section{Kestävyyden haasteita ja mahdollisuuksia ruokasektorilla \\ Haasteet}

On ennustettu, että pelkästään ilmastonmuutoksen takia globaali ruokajärjestelmä tulee kohtaamaan suuria haasteita seuraavan 40 vuoden aikana. Ympäristövaikutusten moninaisuuden, kuten biodiversiteettikysymysten sekä luonnonvarojen niukkuuden takia haasteet ovat vielä suuremmat kuin osaamme tällä hetkellä arvioida. (The Future of Food and Farming... 2011, SCAR 2011).

Hyvin monet tämän hetken ruoantuotannon järjestelmät vaarantavat tulevaan ruoantuotannon kapasiteettia. Ihmisten aikaansaaman typen reaktiivisten muotojen synteesin on arvioitu ylittävän 
planetaariset palautuvuuteen perustuvat rajat jo nelinkertaisesti ja fosforin päästön meriin on arvioitu olevat kymmenkertaisen luonnolliseen päästöön verrattuna, ja päästön kasvun on arvioitu jo ylittävän planetaariset rajat välittömästi (Rockström ym. 2009). Neljäsosa kasvihuonekaasuista on seurausta maankäytöstä, sen muutoksista ja fossiilisten polttoaineiden käytöstä. Maatalous yksinään on biodiversiteetin suurin uhka ja kasteluveden käyttö alentaa uhkaavasti pohjavesiä sekä pilaantuneiden kasteluvesien käyttö ruoan turvallisuutta. Väestönkasvun jatkuessa (yli 8 miljardia vuoteen 2030 mennessä), ruoan tuotannon ja kulutuksen pitäminen tasapainossa tulee aiheuttamaan suuria haasteita. (SCAR 2011).

Suomalaisen elintarviketuotannon suurin haaste on kääntää tuotannonalan asema paikallisesta pintavesien pilaajasta makean veden ekotehokkaaksi ja puhtaan veden lisäarvoa hyödyntäväksi vientiin tähtääväksi toimialaksi. Bioenergian tuotanto on erityisesti metsätalouteen linkittyvälle maataloudelle lisämahdollisuus tässä tilanteessa, jossa elintarviketalouden osuus ilmastomuutoksessa ei ole mitenkään hallitseva.

\section{Mahdollisuudet}

Kestävyyttä elintarvikeketjussa voidaan lisätä kiinnittämällä huomio kestäviin ruokajärjestelmiin ja markkinoihin, kuten luonnonvarojen niukkuuteen ja monimuotoisuuteen (esimerkiksi lähi-, luomu- ja kausiruokatuotannon kehittämisen ja alkuperäisrotujen suojelun kautta), ruokaketjun läpinäkyvyyteen, ruokajätteen/-hävikin minimointiin, vähittäiskauppojen kestävämpään toimintaan (mm. kuljetus- ja sijaintilogistiikan kautta) ja tarkastelemalla kokonaisvaltaisesti koko ketjun toimintaa (mm. tunnistamalla erilaisia tuotantostrategioita ja kulutusidentiteettejä). Panostamalla myös kestävään ruokavalioon, ja sitä kautta esimerkiksi kasvisperäisen ruokavalion mahdollisuuksiin, sokerin ja muiden runsasenergisten hiilihydraattien vähentämiseen, ylipainon ja liikalihavuuden torjumiseen kotitalouksien eriarvoistumisen torjumiseen ruoan osalta $(\mathrm{mm}$. ruoan valmistustaitoja ja terveellisen ruokavalion ymmärtämisen kautta) voidaan kestävyyttä edistää. Kestävyys edellyttää muutoksia myös kulutuksessa, mitä voidaan kehittää esimerkiksi kiinnittämällä huomiota ja vaikuttamalla ruoan kulutuksen saatavuuteen ja edullisuuteen sekä ruoan kulutuksen trendeihin. Huomio on kiinnitettävä myös kuluttajakäyttäytymiseen ja ruoan julkisiin hankintoihin. Politiikkatoimenpiteiden osalta tarvitaan toimenpiteitä yhtenäisen ruokapolitiikan edistämiseksi (kuten kehittämällä malleja ja mekanismeja liiketoimintasektorin ja kansalaisyhteiskunnan sitouttamiseksi kestävän ruokapolitiikan hallitsemiseen), panostusta politiikkatutkimuksen menetelmiin ( $\mathrm{mm}$. implementoimalla politiikan vaikutusarviointimenetelmiä ja tehokkuustutkimusta) sekä kehittämällä tiedon siirtoa tutkijoiden ja politiikan tekijöiden välillä.

YK:n vuosituhannen ekosysteemiarvio (Millenium Ecosystem Assessment) tarjoaa mallin ihmisen ekosysteemeihin aiheuttamien muutosten ja ihmisten hyvinvoinnin tarkasteluun. Ekosysteemiarvioin kantavana ajatuksena on se, että koko hyvinvointimme ja terveytemme perustuu luontoon ja sen tarjoamiin eri palveluihin. Ekosysteemipalveluilla tarkoitetaan kaikkia ihmisen luonnosta saamia aineellisia ja aineettomia hyötyjä. Muutokset eri ekosysteemipalveluissa vaikuttavat hyvinvoinnin eri osa-alueisiin. (Ecosystems and human well-being 2005). Ekosysteemipalvelujen linkittäminen ruokahuoltoon ja hyvinvointiin edellyttäisi, että kaikki ruokatalouden toimijat alkaisivat yhteisesti kehittää luonnonvaroja ja ympäristöä säästävää elintarvikejärjestelmää, sekä sen sosiotaloudellista ja eettistä perustaa, siis suomalaisen ruoan kestävää laatua. Huomio olisi siis kiinnitettävä paitsi siihen, miten kuluttajat saadaan muuttamaan toimintatapojaan, myös siihen millä tekniikoilla ja tuotantojärjestelmillä pystymme tuottamaan ruokaa kestävästi ja millaisia toimenpiteitä tarvitaan politiikkatasolla kestävän ruoantuotannon edistämiseksi. Ekosysteemipalveluun siirtyminen edellyttää muutoksia päätöksenteon tietopohjaan, kustannusten ja hyötyjen tuntemusta sekä ekosysteemien ja hyvinvoinnin välisten yhteyksien parempaa tuntemusta (Naskali 2007).

\section{Käytännön ehdotuksia}

Syksyllä 2011 järjestettiin KULTU-ohjelmassa kaksi työpajaa, johon osallistui noin 100 eri alojen asiantuntijaa, toimijaa ja yritysten edustajaa. Osallistujat tuottivat käytännönläheisiä ja konkreettisia hanke-ehdotuksia kestävän kulutuksen ja tuotannon teemojen osalta ja ruoka-teeman lisäksi tarkasteltavana oli myös liikenteen ja asumisen kestävyys. Ruoka-teeman osalta osallistujat ideoivat 
'Hyvän syömisen lautasmallin` sekä 'Lähikauppa-auto` -idean. Ensimmäisen ehdotuksen kantavana ajatuksena on se, että lautasmalli muokkautuu vuodenaikojen tarjonnan sekä ihmisten omien valintojen ja arvojen mukaan. Tavoitteena on, että lautasmalli auttaa kuluttajia löytämään omiin ruokailutottumuksiinsa ja elämäntilanteeseensa sopivia ratkaisuja, pienentää ruoan ilmastopäästöjä ja muita haitallisia ympäristövaikutuksia huomioimalla kuitenkin ruoan hyvän maun ja vaihtelun. Lähikauppa-autoehdotuksen tarkoituksena on tuoda vähähiilistä kausiruokaa lähitiloilta suoraan kuluttajille ja myydä tuotteita perinteisen kauppa-autojen tapaan. Päämääränä on, että kauppa-auto voisi helpottaa arjen kiirettä ja vähentää asiointimatkoja etenkin haja-astutus ja esikaupunkialueilla. Kuljetuspalvelu tukee myös pientuottajia ja mahdollistaa lähiruoan helpomman saatavuuden. Ehdotusten eteenpäinviemistä on tarkoitus jatkaa tulevaisuudessa muilla foorumeilla.

\section{Kirjallisuus}

Berger, G., Pisano, U., Szlezak, J. \& Csobod, E. 2011. The CORPUS Research Agenda for Sustainable Food Consumpiton in Europe. June 2011.

Ecosystems and Human Well-being. Synthesis. 2005. Millenium Ecosystem Assesment. s. 136.

European Environment Agency, 2010. The European Environment. State and Outlook 2010. Consumption and the Environment.

Forsman-Hugg, S., Katajajuuri, J-M., Paananen, J., Pesonen, I., Järvelä, K., Mäkelä, J. 2009.

Elintarvikeketjun vastuullisuus. Kuvaus vuorovaikutteisesta sisällön rakentamisen prosessista. Maa- ja elintarviketalous 140: $74 \mathrm{~s}$.

Kirveennummi, A., Saarimaa, R. \& Mäkelä, J. 2008. Syödään leväpullia pimeässä. Tähtikartasto suomalaisen ruoan kulutukseen vuonna 2030. Tulevaisuuden tutkimuskeskuksen julkaisuja. $80 \mathrm{~s}$.

Naskali, 2007. Ekosysteemien merkitys taloudelle ja hyvinvoinnille. Suomen kestävän kehityksen toimikunnan kokous 3/2007. METLA/Rovaniemi. Saatavilla internetissä:

http://www.ymparisto.fi/download.asp?contentid=75047

Maailman tila 2010. Kulutuskulttuurista kestävään elämäntapaan. Worldwatch -instituutti. $270 \mathrm{~s}$.

Nellemann, C., MacDevette, M., Manders, T., Eickhout, B.,Svihus, B., Prins, A. G., Kaltenborn, B. P. (Eds). 2009. The environmental food crisis, The environment's role in averting future food crises. A UNEP rapid response assessment. United Nations Environment Programme, GRID-Arendal. 101 s. Saatavilla internetissä: http://www.unep-wcmc.org/medialibrary/2010/09/07/51d38855/FoodCrisis.pdf.

Naskali, A. 2008. Ekosysteemilähestymistapa ja ekosysteemipalvelut. Metsien monimuotoisuuden turvaaminen ja yhteiskunta - avoin seminaari 14.2.2008. METLA/TUK-ohjelma. Saatavilla internetistä: http://www.metla.fi/tapahtumat/2008/tuk/naskali-14-2-08.pdf

Rockström, J., Steffen, W., Noone, K., Persson, Å, Chapin, F.S., Lambin, E., Lenton, T.M., Scheffer, M., Folke, C., Schellnhuber, J.H., Nykvist, B., de Wit, C.A., Hughes, T., van der Leeuw, S., Rodhe, H., Sörlin, S., Snyder, P.K., Costanza, R., Svedin, U., Falkenmark, M., Karlberg, L., Corell, R.W., Fabry, V.J., Hansen, J., Walker, B., Liverman, D., Richardson, K., Crutzen, P. \& Foley, J. (2009). Planetary Boundaries: Exploring the Safe Operating Space for Humanity. Ecology and Society, Vol. 14, No. 2.

Saarinen, M., Kurppa, S., Nissinen, A. \& Mäkelä, J. 2011. Aterioiden ja asumisen valinnat kulutuksen ympäristövaikutusten ytimessä. Consenv-hankkeen loppuraportti. 97 s. Saatavilla Internetistä:

http://www.ymparisto.fi/download.asp?contentid=127955\&lan=fi

SCAR, 2011. Sustainable food consumption and production in a resource-constrained world. The $3^{\text {rd }}$ SCAR Foresight Exercise. 149 p.

Silvennoinen, K. \& Katajajuuri, J-M. Kauppojen ruokahävikki yli kymmenen kiloa suomalaista kohti vuodessa. Tiedote. Saatavana internetissä:

https://portal.mtt.fi/portal/page/portal/mtt/mtt/ajankohtaista/uutiset/Kauppojen\%20ruokah\%E4vikki\%20yli\%20k ymmenen\%20kiloa\%20suomalaista\%20kohti\%20vuodessa

Stehfest E., Bouwman, L., van Vuuren, D.P, den Elzen, M.G.J, Eickhout, B. \& Kabat, P. 2009. Climate benefits of changing diet. Climate Change 95:83-102.

The Future of Food and Farming: Challenges and choices for global sustainability (2011). Final project report. Government Office for Science. $208 \mathrm{~s}$.

Usva, K., Hongisto, M., Saarinen, M., Nissinen, A., Katajajuuri, J.-M., Nurmi, P., Kurppa, S., Koskela, S. 2009. Towards certified carbon footprints of products - a road map for data production - Climate Bonus project report (WP3). VATT-tutkimuksia 143:2: $81 \mathrm{p}$.

Virtanen, Y., Hyvärinen, H., Katajajuuri, J-M., Kurppa, S., Nousiainen, J., Saarinen, M., Sinkko, T., Usva, K., Virtanen, J., Voutilainen, P., Ekholm, P., Grönroos, J., Koskela, S., Väänänen, S. \& Mäenpää, I. Elintarvikeketjun ympäristövastuun taustaraportti. 148 s. Saatavilla Internetistä: 
http://www.laatuketju.fi/laatuketju/www/fi/julkaisut/Microsoft_Word_-_Ketjuvastuu_15_12 final.pdf Watté, J. 2011. Own protein cultivation in Europe. Future Farms and Food in Europe. European Parlament, Brussels, 3rd of February, 2011. pp. 46-50.

YM 2008. Maatalouden vesiensuojelu. Maatalouden vesiensuojelun keinoja.

http://www.ymparisto.fi/default.asp?contentid=173862\&lan=fi 